\title{
THE RIGHT OF ACTION OF A DEPOSITOR WITH FLNDS FOR THE DISHONOR OF HIS CHECK.
}

When a bank receives the funds and checks of a depositor and credits him with them in the usual way, there arises an implied contract on the part of the bank to pay the depositor the amount of his deposits upon demand and in lawful money : I IIorsi on Banks and Banking (3 Ed.) $\$ \S 3 \mathrm{I}$ I, 3 I 2 ; Bank of Kcntucky' v. Wister, 2 Peters, 324 (1829). For refusal to pay, an action of assumpsit will lie by the depositor: MTarine Bank of Chicago v. Bimey', 28 Ill. 90 ( 1862); First National Bank of Lock Havtn v. ITason, 95 Pa. I I 3 (I880); Patterson v. Marini National Bank, 25 W. N. C. I08 (1886); NFiller v. Bank, 37 IV. N. C. 373 (1896).

But the law implies more than this single contract to pay the depositor, on demand, the total amount of his deposits. In the usual course of a depositor's business he is, of course, daily drawing check after check against his deposits. And the questions which it is proposed to discuss here are:

I. If a depositor has sufficient funds in bank and he draws a check against the same, does not the law imply both a contract and a duty on the part of the bank to pay such check on demand, and in lawful money; and if so, then

II. What is the depositor's measure of damages for the refusal of the bank to pay his check under such circumstances? In other words, practically stated, what are the rights of the depositor and the liabitity of the bank in such a case?

I. There can be no doubt, under all the authorities, that the first query must be answered in the affirmative. The rule is well summarized in Citizens' National Bank v. I. \& T. Bank, I19 N. Y. 199 (I 890), where the court says: "The contract between two banks, as implied by law, was that the amount of funds standing to the credit of the plaintiff bank on the defendant's books should be held and paid out upon and according to the plaintiff's checks or order; and a failure to 
pay an order for their payment was a breach of the plaintiff's duty and contract, for which it is legally liable either in tort or upon the contract."

In the case just cited, the form of action was ex contractu; but in the leading case on the subject, Mrarazetti v. Milliams, I B. \& Ad. 4I4 ( $\&_{30}$ ), the declaration was in tort, for breach of duty. The case was most elaborately argued by Brougham and Theisger for the plaintiff and by Sir James Scarlett, Attorney-General, Campbell, Justice and Williams for the defendant, and separate opinions were delivered by Lord Tenterden. C. J., and his associates. The facts were that the plaintiff drew his check for $87 £ .7 \mathrm{~s} .6 \mathrm{~d}$. on the defendant. Sufficient funds had been deposited to meet the check four hours before presentation. "The clerk to whom it was presented, after having referred to a book, said there were not sufficient assets, but that the check might probably go through the Clearing-House. The check was paid on the following day. Under this evidence it was contended by the AttorneyGeneral that the plaintiff, having declared in tort, as for a breach of duty, must be non-suited, inasmuch as he had not proved any damage." The trial judge, however, directed the jury to find for the plaintiff. Upon a motion for a new trial, the court unanimously sustained the right of the plaintiff to sue in tort.

Lord Tenterden, C. J., said :

"It is immaterial in such a case whether the action in form be in tort or in assumpsit... My judgment... proceeds on the ground that the action is founded on a contract between the plaintiff and the bankers, that the latter, whenever they should have money in their hands belonging to the plaintiff, or within a reasonable time after they should have received such money, would pay his check."

Parke, J., said :

"I am of the same opinion. This action being substantially founded on a contract, I think it can make no difference whether it is in tort or in assumpsit. There is no authority for any such distinction."

Taunton, J., said : 
"The plaintiff has a right to have his check paid at the time it was presented, and the defendants are guilty of a wrong by refusing to pay it. The form of the declaration, whether it be in tort or assumpsit makes no substantial difference."

And Patterson, J., said:

"I think the verdict was right. The action is in form founded in tort, but is in substance founded on a contract."

The right to sue in tort for a breach of duty was again upheld in the case of Rolin v. Stezuart, I4 C. B. 595 (1854); and the suit was also in tort in Birchall v. Third Tational Bank, I5 W. N. C. I74 (I884); Schaffner v. Elirman (Ill.), $2 S$ N. E. Rep. 9 I 7 (IS9I); and Rc.x v. Vationai Bank of Ripublic (not yet reported), C. P. No. 2 of Philadelphia County (December, I 895). In Prchn r. Royal Bank of Liżerpool, L. R. 5 Exch. 97 (1870), however, the suit was cx contractu; and such, too, as before observed, seems to have been the form of complaint in Citiscns National Bank v. I. \& T. Bank, II N. Y. 199 (I 890 ).

While the right to sue in tort, as for a breach of duty lias been declared in emphatic and unmistakable terms in Mllarasitti $v$. Williams, and some of the later cases just cited, yet the reasons why a failure to pay is a breach of duty, warranting, therefore, such form of action, are but scantily given in the opinions, the argument in most of the cases consisting largely in the statement of the conclusion. Thus, for example, in IIarasiti $v$. Irillians, it is simply stated as a conclusion that the defendants "were guilty of a wrong in refusing to pay" the plaintiff's check, and a sinilar statement, without more, is made in Citiscns' lational Bank v. I. \& T. Bank, supra, though in Birchall v. Third Lational Bank, supra, Hare, P. J., observes: "Inasmuch as the bank has the use of the money, it undertakes a duty :" while. in Patterson r. Itarine Irxtional Bank, supra, Paxson, C. J., delivering the opinion of the court, declared that a bank is an institution of a quasipublic character, and that " there is something more than a breach of contract in such cases. There is a question of pubi:c polic: involved." Further fragmentary reasons may, perhap; be found in the cases. In the absence, however, of 
any complete judicial statement, the probable reasons why stich an action is sustainable may be summarized as follows:

The relation between a bank and its depositor is not simplythat of debtor and creditor. It is this and more. The bank receives its depositor's notes and checks. It undertakes the collection of the same, and uses the proceeds in its business: in virtue of which undertaking and use, coupled further with the quasi-public character of the bank, the law implies not merely a contract but a duty to pay its depositor's check, when presented. For breach of this duty to pay, of course, the proper action is in tort. The last noted reason, viz., that the business of a bank is affected with a public interest is, it is believed, the essential and fundamental 1 zason and thus brings the cases within the ruling of the broad and well-recognized principle that whenever a defendant's busiress is, by reason of the services which he renders and the use to which his property is put, affected with a public interest, a breach of contract made by such a defendant in the way of his business is, by legal implication, also a breacil of duty. Such is the familiarstatus of a wharfinger, an innkeeper, a common carrier, and, as showing the progress of the law, such more recently has been declared to be the status of the owners of elevators and warehouses where grain or other property is stored: IFun v. Illinois, 94 U. S. I 13 (1876); Pioplc v. Budd, 143 U. S. 528 (I891).

It is worthy of mention that in none of the above cited cases in which the action was in tort was there any special damage, or malice proved. As substantial damages (as we shall see infra) may, notwithstanding, be recovered for the dishonor of a depositor's check, the practical advantage of suing in tort is obvious, $i . c$., in such an action the jury have a greater latitude in assessing the damages than in actions $e x$ contractu, and the courts are, therefore, more reluctant about interfering with their verdicts. In Prelln v. Royal Bank of Liz'erpool, and Citisens' National Bank r. I. \& T. Bank, supra, in which the action was ex contratu, only such sums were claimed and recovered as were arithmetically demonstrated to be due. 
Of course, the bank must make paynent of the depositor's check in lawful money. This has been repeatedly held in the Westem States in cases in which deposits were made of bankbills of the so-called "wild-cat banks." Credit having been given in the usual way for their nominal value in dollars and cents, the courts have uniformly held that bills similar to those received, or eren the identical bills, could not be forced upon the depositor, but that the bank's liability could only be discharged in grood money, such as under the law was then a legal tender: I Morsi on Banks and Banking (3 Ed.) \$ 3 I2; Thompsonv v. Riggs, 5 Wall. 678 (1866); Mearine Bank of Chicago 1. Chantlor, 27 Ill. 525 (I S62); Marine Bank of Chicago $\because$ Rushimore, 28 Ill. 463 (I 862); Willetta v. Paine, 43 IIl. 433 (I 867 ). This view was also taken in Rexv. Tational Bank of Republic, supra, where the bank, on account of the financial stringency of the times, refused payment of plaintiff's check except in a Clearing-House due-bill, which the holdier of the check refused to accept.

II. We come, then, to the second breach of the subject, viz. : What is the depositor's measure of damages for the refusal of the bank to pay his check when presented, provided the bank then has sufficient of the depositor's funds with which to pay the check?

On this head, the decisions are apparently uniform, that for the simple refusal of his check under such circumstances, without proof of any special injury, or malice, the depositor is entitled to recover substantial damages: Rolin v. Stiwart; Patterson v. IIarine National Bank; Birchall v. Thivd National Bank; Schaffnir v. Elmman; supra. By substantial damages is meant "not nominal, nor excessive, but reasonable and temperate damages," such as the jury shall judge to be a reasonable compensation for the injury the plaintiff has sustained from the dishonor of his check. Such was the direction of Lord Campbell to the jury at the trial in Rolin v. Stecart, which direction was afterwards adopted by the Court of Common Pleas, and declared by Cresswell, J., to be " perfectiy right." In Prclin v. Rol'al Bank of Livirpool, supra, Felly. C. B., declared that the jury were " entitled to consicler 
all the probabilities and circumstances of the case, and to give reasonable damages accordingly." The following excerpt from the opinion of Martin, B., in the same case, at once clearly defines general damages and distinguishes the same from the several other kinds of damages:

"Now with respect to damages in general, they are of three kinds-first, nominal damages, which occur in cases where the judge is bound to tell the jury only to give such, as, for instance, when the seller brings an action for non-acceptance of goods, the price of which has risen since the contract was made. The second is general damages and their nature is clearly stated by Cresswell, J., in Rolin v. Stcwart. They are such as the jury may give when the judge cannot point out any measure by which they are to be assessed except the opinion of a reasonable man. Thirdly, special damages are given in respect of any consequence reasonably or probably arising from the breach complained of."

To the foregoing list, the learned judge might have added punitive or exemplary damages, of which mention will be made hereafter.

To the rule that on proof of the refusal to honor his check, without more, the depositor is entitled to recover substantial or general damages, there is among the decided cases one that is apparently contradictory. This is the case of Marascti v. I'illiams, supra, in which the Court of King's Bench held that the plaintiff was entitled to recover only nominal damages. But, in Rolin v. Stcueart, supra, Cresswell, J., in sustaining the above-quoted direction of Lord Campbell to the jury, that they give " not nominal or excessive, but reasonable and temperate damages," declared further: "I think the case of Marastit v. Williams goes the full length of justifying that direction. ... The report of that case does not show what the direction to the jury was on the subject of damages, but it seems to have been taken for granted that the plaintiff had sustained no actual damage." Thus explained, it is clear that Iraraziti v. Irilliams is not an exception to the current of decisions on the question. Properly construed, it does not limit the recovery to nominal damages, and no subsequent 
case, it is believed, contains any such limitation. On the other hand, Marasetti v. Irilliams does decide that special damages need not be proved to entitle to recover, and the subsequent cases follow the leading case in this respect.

We thus have a series of adjudged cases all ruling that upon the plaintiff simply proving that the bank dishonored his check he is entitled to recover substantial damages.

The reason for the ruling referred to is not, however, always clearly stated in the opinions, and the reasons in some of the cases are apparently conflicting. It may be instructive, therefore, to attempt to deduce from these decisions the true principle upon which it is founded.

Upon inspection, then, it will be seen that in Masarett v. Willians; Rolin v. Stewart; Birchall v. Third National Bank, and Schaffner v. Elmman, the reason given the holder of the check for refusing payment was that the plaintiff did not have sufficient funds to pay it. This statement was untrue, and was due, in each case, to the mistake of the book-keeper. Such an untrue statement was, of course, an imputation on the plaintiff's solvency, represented him as in bad or failing circumstances, and tended to injure him in his business. From these decisions, standing alone, it might, therefore, be inferred that to entitle the plaintiff to recover, he must prove facts and circumstances which would amount to a slander by the bank upon his credit as a merchant or trader.

But in certain others of the cases cited supra, viz.: Prelun $\therefore$ Rojal Bank of Liverpool, Citisens' N'Tational Bank v. I. \& $T$. Bank, Rex v. National Bank of Republic, and Patterson r. IIarine National Bank, the reasons given the holder of the check for refusing payment, as well as all the facts and circumstances of the case, flatly refuted the idea of any imputation upon the plaintiff's solvency, or any slander of his credit. Thus, in Prelun v. Roy'al Bank of Liz'crpool, supra, the defendant bank had accepted certain drafts of the plaintiffs, payable at three months, and the plaintiffs had deposited sufficient funds to meet the drafts. Before they came due, however, the bank became insolvent. The plaintiffs thereupon deposited sufficient funds with another banking-house to meet them, and 
when they subsequently came due and were presented to the defendant bank for payment, the holders were informed of the bank's insolvency and that the plaintiffs had arranged with the other banking-house to pay the same. The drafts were thereupon protested, according to mercantile usage, and the second banking-house then accepted them supra protest and paid them. Under this state of facts, counsel for the defendant bank sought to distinguish the case from the class of cases above mentioned, and argued that:

"The cases as to the refusal by a banker to honor his customer's draft have no application. Such a refusal represents the customer as having committed a fraud in drawing upon or accepting bills payable at a bank where he has no assets; or, at least, as having made a false statement as to a fact within his own knowledge, and the injury to his credit which this representation causes is the ground on which he is held entitled to damages. But the cause of the refusal here being the insolvency of the bank, no such consequence can follow. It is, then, nothing but the ordinary case of dishonor of a bill by the acceptor; and it is settled law that in such a case, as in all cases where the demand is a mere money demand, nothing can be recovered beyond the amount of the bill and interest." (Page 96.)

The court, however, declined to adopt this view, Kelly, C. B., declaring :

"If the bills had simply been dishonored, and the plaintiffs had brought their action, then, without proof of any such special damage, the jury would, on the principle of Rolin $\mathrm{v}$. Stezuart and Marazeiti v. Williams, have been entitled to consider all the probabilities and circumstances of the case, and to give reasonable damages accordingly." A verdict for substantial damages was accordingly sustained.

Again, under the facts in Citiscns' National Bank v. I. \& T. Bank, supra, there was no slander of the plaintiff's credit. In this case the plaintiff sold certain drafts on the defendant to IV. \& Co., whose book-keeper forged certain endorsements and the drafts were presented by his endorsee to defendant and paid. Subsequently, the drafts were returned by the 
defendant to the plaintiff, and, being then demanded by W. \& Co., the plaintiff again delivered the same to IV. \& Co., who thereupon presented the said drafts to the defendant. Upon presentation, the defendant admitted it had sufficient funds of the plaintiff on deposit to pay, but refused payment for the reason that it had previously paid the same drafts. The court, however, deciared that the principle of Marazetii $v$. Williams "governs this case," and upheld a verdict in substantial damages.

Patterson v. Ilturine Vational Bank, supra, also negatives the view that actual slander of the plaintiff's business credit is necessary to recover. In this case the plaintiff drew his check to his own order for the total amount of his deposits and presented it for payment himself. There being no third person concerned in the transaction, there could, of course, be no slander of the plaintiff's credit. The Supreme Court of Pennsylvania, nevertheless, ruled that the plaintiff was entitled to recover substantial damages.

In the light of these decisions, slander of the plaintiff's credit is plainly not the true basis of the ruling, but is simply one "of the circumstances of the case" which goes in aggravation of the damages. Instead, its real foundation is, it is conceived, that given by Paxson, C. J., in Patterson v. Marine National Bank, as follows:

"A bank is an institution of a quasi-public character. It is chartered by the government for the purpose, inter alia, of holding and safely keeping the moneys of individuals and corporations. It receives such moneys upon an implied contract to pay the depositor's check upon demand. Individual and corporate business could hardly exist for a day without banking facilities. At the same time, the business of the community would be at the mercy of banks if they could at their pleasure refuse to honor their depositor's checks and then claim that such action was the mere breach of an ordinary contract for which only nominal damages could be recovered, unless special damages were proved. There is something more than a breach of contract in such cases; there is a question of public policy involved, as was said in Bank v. Mason, 
$95 \mathrm{~Pa}$. I 13, and a breach of the implied contract between the bank and its depositor entitles the latter to recover substantial damages."

Special damages may, however, also be recovered. They are such a loss as must be specially proved on the trial by evidence. Such damages, according to the definition of Martin, B., before quoted, "are given in respect of any consequence reasonably or probably arising from the breach complained of "- $\ell$. $g$., if the plaintiff were to prove that his customers, A., B. and C., who theretofore had dealt with him in his business, had, in consequence of the dishonor of his check, been led to suspect he was in bad financial condition, and refused to deal further with him, such evidence would entitle the plaintiff to recover special damages. See Larios v. Gurety, L. R. 5 P. C. 346 (1873), where both general and special damages were claimed.

Punitive damages, or damages by way of punishment, sometimes called exemplary damages, may also be recovered if the evidence establishes that the bank acted in reckless disregard of the plaintiff's rights or with malice against him in refusing to pay his check. See Patterson v. Marine National Bank, supra.

In a proper case, therefore, special and punitive damages, as well as general damages, may be recovered by a depositor for the dishonor of his check.

Philadelphia. 